\title{
KONCEPCJA ZMODYFIKOWANEGO WSKAŹNIKA WYPLACALNOŚCI JAKO ALTERNATYWA DLA TRADYCYJNYCH WSKAŹNIKÓW OCENY PLYNNOŚCI FINANSOWEJ
}

\begin{abstract}
Streszczenie
W artykule przedstawiono problemy związane z analizą płynności finansowej przedsiębiorstwa, dokonywaną na podstawie statycznych oraz dynamicznych wskaźników, jak również innych powszechnie znanych mierników płynności finansowej. Taka analiza jest obciążona wieloma brakami. Z tego względu nie pozwala na rzetelną ocenę wypłacalności przedsiębiorstwa. W związku z tym, zaprezentowano koncepcję zmodyfikowanego wskaźnika wypłacalności jako alternatywę dla tradycyjnie stosowanych wskaźników płynności finansowej. Zastosowanie zmodyfikowanego wskaźnika wypłacalność umożliwia precyzyjniejszą ocenę zdolności przedsiębiorstwa do regulowania zobowiązań. Zwrócono również uwagę na kwestię sezonowości sprzedaży w ocenie płynności finansowej przedsiębiorstwa.

W artykule wykorzystano przykład liczbowy, który obrazuje skale różnic w ocenie płynności finansowej, przeprowadzonej dzięki zastosowaniu tradycyjnych wskaźników płynności finansowej oraz zmodyfikowanego wskaźnika wypłacalności.
\end{abstract}

Słowa kluczowe: płynność finansowa, wskaźniki oceny płynności finansowej, analiza finansowa

\section{MODIFIED LIQUIDITY RATIO AS ALTERNATIVE TO TRADITIONAL FINANCIAL LIQUIDITY INDICATORS}

\section{Summary}

This paper investigates problems associated with financial liquidity analysis based on static and dynamic indicators, and other widely known measures of liquidity. Such analysis has many shortcomings and, consequently, does not allow for a reliable assessment of the solvency of a company. Therefore, the author presents the concept of modified liquidity ratio as an alternative to the traditionally used indicators of liquidity. The modified liquidity ratio makes it possible to perform a more precise assessment of a company's capacity to settle its liabilities. The author also pays attention to the issue of seasonality in the evaluation of financial liquidity.

This paper provides a numerical example to illustrate the differences in the assessment of liquidity conducted using traditional indicators of liquidity and the modified liquidity ratio.

Key words: financial liquidity, liquidity indicators, financial analysis

${ }^{1}$ Dr Paweł Wnuczak - Katedra Finansów, Akademia Leona Koźmińskiego; e-mail: pawelw@ kozminski.edu.pl. 


\section{Wstęp}

Przez pojęcie płynności finansowej należy rozumieć zdolność firmy do terminowego regulowania zobowiązań. Utrata tej zdolności może prowadzić do wstrzymania dostaw czynników produkcji, a w efekcie nawet do bankructwa. Co więcej, zakłócenia płynności finansowej danego przedsiębiorstwa negatywnie wpływają na jego relacje $z$ kontrahentami gospodarczymi oraz podważaja zaufanie instytucji finansowych. $Z$ tych powodów analiza oraz planowanie płynności finansowej stanowia jedne z najważniejszych aspektów zarząazzania finansami przedsiębiorstwa.

W ocenie płynności finansowej przedsiębiorstwa często stosuje się statyczną analizę wskaźnikowa, przeprowadzaną na podstawie danych bilansowych przedsiębiorstwa. W tym ujęciu, płynność przedsiębiorstwa jest mierzona za pomocą wskaźników obejmujących różne relacje aktywów obrotowych do zobowiązań krótkoterminowych [Nowak, 1998, s. 152]. Pomimo istnienia kilku statycznych wskaźników płynności, analiza dokonywana na bazie danych bilansowych, zawartych w publikowanych sprawozdaniach finansowych, nie pozwala na precyzyjną ocenę wypłacalności przedsiębiorstwa. W związku z tym, coraz częściej w ocenie płynności finansowej wykorzystuje się przepływy gotówkowe. Dzięki nim jest możliwe ustalenie całej gamy wskaźników, które w sposób syntetyczny opisuja ,gospodarkę pieniężna” przedsiębiorstwa [Zarz̨adżanie plynnościq..., 2007, s. 52]. Najczęściej wskaźniki te są ujmowane w dwóch grupach: wskaźniki wydajności gotówkowej oraz wskaźniki wystarczalności gotówki [Cash flow ..., 1993, s. 60]. Jednak, podobnie jak statyczne wskaźniki, powyższe wskaźniki również uniemożliwiaja precyzyjną ocenę płynności finansowej firmy, mimo ich dynamicznego charakteru. Teoria i praktyka zarządzania finansami przedsiębiorstwa zna także inne mierniki płynności finansowej przedsiębiorstwa, a wśród nich wskaźniki prezentujące relację płynnych aktywów do planowanych, dziennych obciążeń finansowych oraz wskaźnik płynności Lambda.

Zarówno statyczna, dynamiczna, jak i inne powszechnie stosowane analizy wskaźnikowe moga prowadzić do błędnych wniosków dotyczących oceny płynności finansowej przedsiębiorstwa. Z tego względu w ramach niniejszego opracowania jego autor podją próbę opracowania uniwersalnego wskaźnika pomiaru płynności, umożliwiającego przeprowadzenie bardziej precyzyjnej oceny przyszłej wypłacalności finansowej przedsiębiorstwa. Ponadto, zwrócono uwagę na problem sezonowości sprzedaży w ocenie płynności finansowej przedsiębiorstwa.

\section{Ocena możliwości wykorzystania statycznych i dynamicznych wskaźników w ocenie płynności finansowej przedsiębiorstwa}

Powszechnie stosowany sposób monitorowania przedsiębiorstwa w zakresie płynności polega na kalkulacji następujących, statycznych wskaźników:

- $\quad$ wskaźnika bieżącej płynności,

- $\quad$ wskaźnika wysokiej płynności, 
- wskaźnika wypłacalności środkami pieniężnymi, zwanego również wskaźnikiem gotówkowego pokrycia zobowiązań krótkoterminowych [Horrigan, 1965, s. 559; Analiza wplymu wskaźników..., 2012, s. 282; Analiza wskaźnikowa..., 2009, s. 135-140; Kusak, 2004, s. 44].

Wszystkie powyższe wskaźniki mierzą relacje między majątkiem obrotowym a bieżącymi zobowiązaniami [Analiza ekonomiczna..., 2001, s. 107]. Pierwszy z nich (wskaźnik bieżącej płynności) obrazuje relacje aktywów obrotowych w stosunku do zobowiazzań krótkoterminowych [Walter, 1957, s. 30-43; Kirkham, 2012, s. 1-13; Principle of Corporate..., 2011, s. 718-719; Principle of Corporate..., 1998, s. 98-99; A cash..., 1980, s. 32-33]. Przyjmuje się, że wartość tego wskaźnika dla przedsiębiorstw, utrzymujących zdolność do regulowania bieżących zobowiązań, powinna zawierać się w przedziale: 1,2-2,0 [Kusak, 2004, s. 44; Gąsiorkiewicz, 1999, s. 126; Sierpińska, 1994, s. 80]. Wartość powyżej 2,0 może oznaczać występowanie zjawiska nadpłynności, a poniżej 1,2 - problemy z utrzymaniem płynności finansowej. Jednocześnie należy wyraźnie podkreślić, że w zależności od branży oraz specyfiki przedsiębiorstwa (np.: struktury aktywów obrotowych oraz zobowiązań krótkoterminowych, okresów rotacji należności, zapasów i zobowiązań) trzeba rozmaicie interpretować wartości powyższego wskaźnika. Jest to jednoznaczne z tym, że wartość 2,0 powyższego wskaźnika może oznaczać zarówno brak płynności, jak i nadpłynność finansową w przypadku dwóch różnych przedsiębiorstw.

Struktura aktywów obrotowych i zobowiązań krótkoterminowych ma wpływ na ocenę płynności firmy, stąd dokładniejszych informacji na temat kondycji płatniczej przedsiębiorstwa może dostarczać wskaźnik szybkiej płynności. Stanowi on relację aktywów obrotowych pomniejszonych o wartość najmniej płynnej ich części - zapasów w stosunku do zobowiązań krótkoterminowych [Principle of Corporate..., 1998, s. 98-99; A cash..., 1980, s. 32-33]. Przyjmuje się, że wartość wskaźnika na poziome 1,0 i więcej wskazuje na utrzymywanie płynności finansowej na satysfakcjonującym poziomie [Ostaszewski, 1991, s. 54-55; Nowak, 1998, s. 157]. Jednak, podobnie jak w przypadku pierwszego z omawianych wskaźników, interpretacja wartości wskaźnika będzie zależała od wielu, wyżej wymienionych, czynników.

Pogłębiona analiza bieżących możliwości płatniczych przedsiębiorstwa może być dokonana na podstawie wartości wskaźnika wypłacalności środkami pieniężnymi (wskaźnika gotówkowego pokrycia zobowiązań krótkoterminowych), [Bednarski, 2001, s. 78-81]. Wskaźnik wypłacalności środkami pieniężnymi pokazuje, w jakim stopniu środki pieniężne pokrywają zobowiązania krótkoterminowe. Wyraża on zatem zdolność przedsiębiorstwa do natychmiastowego regulowania zobowiązań [Principle of Corporate..., 2011, s. 718-719]. Im wyższy poziom wskaźnika, tym większa zdolność przedsiębiorstwa do regulowania zobowiązań krótkoterminowych. Niektórzy autorzy dowodzą, że wielkość wskaźnika gotówkowego pokrycia zobowiązań krótkoterminowych powinna utrzymywać się na poziomie około 20\% [Szczepaniak, 1992, s. 157]. Inni uważają, że wartości typowe mieszczą się w przedziale od 5\% do 35\% [Nowak, 1998, s. 152].

Powyższe problemy interpretacyjne, dotyczące wszystkich statycznych wskaźników płynności, wynikają głównie z ich statycznego charakteru. Mierzą one płynność na podstawie historycznych danych bilansowych. Tymczasem wypłacalność przedsiębiorstwa zależy nie tylko od wartości posiadanych środków pieniężnych oraz od stanu zobowią- 
zań w danym dniu. Jest ona w zasadniczym stopniu uzależniona od przyszłych przepływów pieniężnych. W związku z tym, w celu wyeliminowania powyższej niedoskonałości, można rozważyć zastosowanie dynamicznych wskaźników oceny płynności finansowej. Pozwalają one analizować płynność na podstawie zdolności przedsiębiorstwa do generowania gotówki z działalności operacyjnej [An Analysis of..., 1991, s. 64-91]. Wśród dynamicznych wskaźników oceny płynności finansowej wyróżnia się wskaźniki wydajności gotówkowej oraz wskaźniki wystarczalności gotówki. Pierwsze z nich obrazuja w jakiej relacji pozostaje gotówka uzyskana z działalności operacyjnej w stosunku do sprzedaży lub aktywów ogółem [Zarżadzanie plynnościq..., 2007, s. 52]. Powyższe wskaźniki wyrażają zatem zdolność odpowiednio sprzedaży albo aktywów do generowania nadwyżek gotówki operacyjnej. Im wyższe są wskaźniki wydajności gotówkowej, tym większe możliwości przedsiębiorstwa w zakresie finansowania różnych wydatków [Kusak, 2004, s. 56].

Druga grupę wskaźników, opartych na przepływach gotówkowych z działalności operacyjnej, stanowią wskaźniki wystarczalności gotówki. Przedstawiają one relację między gotówką wygenerowaną z działalności operacyjnej a różnego rodzaju zobowiązaniami [Developing Ratios..., 1991, s. 63-70; An Analysis of..., 1991, s. 64-91]. Ilustrują one więc możliwości przedsiębiorstwa $\mathrm{w}$ zakresie regulowania jego zobowiązań. Podobnie jak w przypadku wskaźników wydajności gotówkowej, wysoka wartość wskaźników wystarczalności gotówki dowodzi dobrej kondycji płatniczej firmy.

W odniesieniu do dynamicznych wskaźników płatności literatura przedmiotu nie podaje wartości oczekiwanych, świadczących o dobrej kondycji płynnościowej przedsiębiorstwa. Jednak podkreśla się, że pożądanym kierunkiem zmian jest wzrost ich poziomu w czasie, a dobrą bazą do porównań tych wskaźników są dane średniobranżowe [Zarzadzanie plynnościq..., 2007, s. 53].

Analogicznie jak w stosunku do statycznych wskaźników płynności, również interpretacja wartości wskaźników dynamicznych przysparza wiele problemów. Co prawda, w tym przypadku analiza opiera się na danych dynamicznych (na przepływach operacyjnych), lecz takie podejście do analizy płynności pomija przede wszystkim takie kwestie, jak stan początkowy środków pieniężnych, który także determinuje pozycje płynnościową przedsiębiorstwa, oraz przypływy inwestycyjne i finansowe.

Wśród metod pomiaru płynności finansowej na uwagę zasługują wskaźniki prezentujące relację płynnych aktywów do planowanych dziennych obciążeń finansowych. Do takich miar zalicza się:

- $\quad$ wskaźnik dziennej płynność finansowej stanowiący iloraz aktywów płynnych (należności, papierów przeznaczonych do obrotu i gotówki) oraz planowanych dziennych kosztów pieniężnych. Określa on liczbę dni, w ciagu których firma może prowadzić działalność operacyjna, stosując w tym celu najbardziej płynne aktywa;

- $\quad$ wskaźnik dziennego dyspozycyjnego pieniądza będący relacją między stanem gotówki powiększonej o krótkoterminowe papiery przeznaczone do obrotu a planowanymi dziennymi kosztami pieniężnymi. Wyznacza on liczbę dni, w ciągu których firma może prowadzić działalność operacyjna, wykorzystując w tym celu jedynie gotówkę i papiery przeznaczone do obrotu; 
- $\quad$ wskaźnik okresu bezpieczeństwa gotówkowego stanowiący relację między stanem aktywów płynnych a planowanymi dziennymi wydatkami operacyjnymi, inwestycyjnymi i finansowymi. Informuje on przez ile dni firma może regulować swoje zobowiązania (operacyjne, inwestycyjne oraz finansowe), wydając na ten cel najbardziej płynne aktywa [Analysis of..., 1993, s. 137; Zarzqdzanie plynnościq..., 2007, s. 70].

Pomimo swoich niewątpliwych zalet informacyjnych, powyższe wskaźniki bazują na wartości aktywów płynnych wyznaczonej na dany dzień, a nie uwzględniają przyszłych przepływów pieniężnych, które moga w zasadniczy sposób oddziaływać na sytuację płynnościowa przedsiębiorstwa. Fakt ten należy uznać za ważne ograniczenie w zakresie zdolności powyższych mierników do oceny płynności finansowej przedsiębiorstwa.

Miara płynności finansowej, stosującą przyszłe strumienie przepływów pieniężnych, jest wskaźnik płynności Lambda. Przyjmuje on postać ilorazu początkowych wartości najbardziej płynnych zasobów (środków pieniężnych, krótkoterminowych papierów do obrotu oraz możliwej do wykorzystania gotówki z linii kredytowej) powiększonych o prognozowany przepływ operacyjny oraz odchylenia standardowego przepływów operacyjnych [The measurement..., 1982, s. 290-303; Corporate Liquidity..., 1993, s. 374; Cash flow: Another..., 1993, s. 55-58]. Zatem, wskaźnik płynność Lambda określa wielkość potencjalnych zasobów płynnych, przypadających na odchylenie standardowe. Im wyższa jest jego wartość, tym wyższą płynnością charakteryzuje się analizowane przedsiębiorstwo. Jednak również ta metoda oceny płynności finansowej przedsiębiorstwa nie jest pozbawiona istotnych mankamentów. Przede wszystkim wskaźnik płynności Lambda nie uwzględnia przepływów pieniężnych z działalności finansowej i inwestycyjnej, które, podobnie jak przepływy operacyjne, wpływają na kondycję płatniczą firmy. Poza tym, aby policzyć wartość oczekiwana przepływów operacyjnych i odchylenie standardowe, jest potrzebnych klika obserwacji [Analiza wskaźnikowa..., 2009, s. 159].

Podsumowując, wyżej wymienione wskaźniki płynności, zarówno statyczne, jak i dynamiczne, ze względu na przedstawione uproszczenia nie pozwalają na precyzyjne definiowanie zdolności przedsiębiorstwa do spłaty zobowiązań. Czynnikami decydującymi o ocenie płynności są przede wszystkim wartości przyszłych wpływów oraz przyszłych wydatków przedsiębiorstwa. Ich wartość jest uzależniona od wartości przyszłych przychodów i kosztów oraz od: terminów spłaty należności, zobowiązań krótkoterminowych, a także zapłaty za zakupione zapasy [Kusak, 2004, s. 44-47]. Istotne znaczenie dla ustalania płynności finansowej przedsiębiorstwa będą również miały: stan środków pieniężnych na początek analizowanego okresu oraz zobowiązania kredytowe i rozkład w czasie ich spłaty. Żadna z zaprezentowanych metod pomiaru płynności nie ujmuje łącznie dwóch czynników decydujących o wypłacalności przedsiębiorstwa: stanu początkowego gotówki i prognozowanych, całkowitych przepływów pieniężnych. Ponadto, nie uwzględniają one sezonowości sprzedaży i jej ewentualnego wpływu na płynność finansowa przedsiębiorstwa.

Biorąc pod uwage powyższe argumenty, nietrudno zauważyć, że analiza płynności finansowej przedsiębiorstwa, dokonana na podstawie zaprezentowanych wskaźników, może prowadzić do błędnych wniosków dotyczących oceny wypłacalności. W związku z tym, w kolejnym podrozdziale autor przedstawił koncepcje pomiaru płynności fi- 
nansowej, opartą na kalkulacji wskaźników, które precyzyjniej oddają zdolność firmy do terminowego regulowania zobowiązań.

\section{Koncepcja zmodyfikowanego wskaźnik wypłacalności (ZWW)}

Jak wynika z niniejszych rozważań, wskaźniki statycznej i dynamicznej oceny płynności finansowej, choć powszechnie stosowane, nie pozwalaja precyzyjnie określać wypłacalności firmy. Główne ograniczenie tych wskaźników polega na tym, że żaden z nich nie uwzględnia łącznie wszystkich podstawowych determinant płynności finansowej, to znaczy:

- stanu początkowego środków pieniężnych,

- planowanych, przyszłych, całkowitych przepływów pieniężnych (przepływów operacyjnych, inwestycyjnych oraz finansowych).

W praktyce precyzyjne planowanie płynności finansowej przedsiębiorstwa odbywa się dzięki odpowiednio skonstruowanemu modelowi finansowemu. W ramach takiego modelu są opracowywane budżety cząstkowe: budżety planowanych przychodów i kosztów, budżet nakładów inwestycyjnych, budżet zewnętrznych źródeł finansowania działalności oraz zapotrzebowania na kapitał obrotowy. W wyniku konsolidacji przygotowanych budżetów cząstkowych opracowuje się: rachunek zysków i strat, rachunek przepływów pieniężnych i bilans. Projekcja rachunku przepływów pieniężnych przedsiębiorstwa umożliwia ustalenie prognozowanych sald gotówki na koniec analizowanych okresów. Dodatnia wartość salda gotówki oznacza, że biorąc pod uwagę przyjęte do planowania założenia, firma utrzyma płynność finansową [Zaawansowane techniki ..., 2010, s. 323-333].

Dokładna ocena płynności finansowej przedsiębiorstwa polega zatem na oszacowaniu przyszłego salda gotówki. Uwzględniając konstrukcję rachunku przepływów pieniężnych, formułę pozwalająca na wyznaczenie planowanego salda gotówki na koniec roku można zapisać w następujący sposób²:

$$
G_{n+1}=G_{n}+S_{n+1}-K_{n+1}+A_{n+1}+\Delta Z_{n+1}+\Delta N_{n+1}+\Delta Z K_{n+1}-I_{n+1}-Z K F_{n+1},
$$

gdzie:

$G_{\mathrm{n}+1}$ - planowane saldo środków pieniężnych na koniec analizowanego roku, $G_{\mathrm{n}}-$ saldo środków pieniężnych na początek analizowanego roku, $S_{\mathrm{n}+1}-$ planowana wartość przychodów w analizowanym roku, $K_{\mathrm{n}+1}$ - planowana wartość kosztów operacyjnych w analizowanym roku, $A_{\mathrm{n}+1}$ - planowana wartość kosztów amortyzacji w analizowanym roku, $\Delta \mathrm{Z}_{\mathrm{n}+1}$ - planowana zmiana stanu zapasów w analizowanym roku, $\Delta \mathrm{N}_{\mathrm{n}+1}$ - planowana zmiana stanu należności w analizowanym roku, $\Delta \mathrm{ZK}_{\mathrm{n}+1}$ - planowana zmiana stanu zobowiązań krótkoterminowych, $\mathrm{z}$ wyjątkiem pożyczek i kredytów, w analizowanym roku, $I_{\mathrm{n}+1}$ - planowana wartość wydatków inwestycyjnych w analizowanym roku,

\footnotetext{
2 Prezentowana formuła pomija wpływy środków pochodzących ze źródeł obcych i od właścicieli oraz kwestie związane z rozliczeniami międzyokresowymi i rozliczeniem rezerw.
} 
$Z K F_{n+1}$ - planowana spłata krótkoterminowych zobowiązań finansowych w analizowanym roku.

Może się okazać, że analityk zewnętrzny, badający płynność finansową podmiotu, nie będzie dysponował informacjami na temat planowanych wartości poszczególnych składników powyższej formuły. Wówczas może on podjąć próbę zaprognozowania ich lub przeprowadzić analizę, przyjmując, że część danych finansowych w roku następnym utrzyma się na poziomie z roku ubiegłego. W dalszej części artykułu zaprezentowano podejście, oparte na założeniu, że większość danych finansowych w analizowanym roku przyjmie wartości historyczne. Jednak należy wyraźnie zaznaczyć, że analityk może zaplanować wszystkie lub wybrane komponenty, opisanej wyżej, formuły na podstawie powszechnie dostępnych informacji.

Zakładając, że analiza będzie prowadzona na podstawie danych historycznych, możliwe jest wprowadzenie kilku uproszeń do opisanej formuły. Po pierwsze, nie znając danych prognozowanych na analizowany rok, można przyjąć założenie, że osiagnięte przez przedsiębiorstwo wyniki finansowe w analizowanym roku nie będą znacznie różniły się od tych z ubiegłego. Dla celów prowadzonej analizy płynności, wartości planowanych przychodów, kosztów i nakładów inwestycyjnych w analizowanym roku ukształtują się więc na poziomie z roku poprzedniego ${ }^{3}$. Po drugie, biorąc pod uwagę, że firma utrzyma poziom przychodów i kosztów z poprzedniego roku, a zmianie nie ulegna wskaźniki rotacji zapasów, należności i zobowiązań, nie wystąpi wzrost zapotrzebowania na kapitał obrotowy. Kolejne uproszczenie dotyczy spłaty zobowiązań finansowych w tym okresie. Wartość tę można odczytać z bilansu spółki, przygotowanego na koniec poprzedniego roku, z pozycji zobowiązań krótkoterminowych z tytułu kredytów i pożyczek, emisji papierów wartościowych i innych zobowiązań finansowych. Uwzględniając powyższe uproszczenia, formuła umożliwiająca wyznaczenie planowanego salda gotówki na koniec badanego roku przyjmie następujący kształt:

$$
G_{n+1}=G_{n}+S_{n}-K_{n}+A_{n}-I_{n}-Z K F_{n+1},
$$

gdzie:

$G_{n+1}$ - planowane saldo środków pieniężnych na koniec analizowanego roku,

$G_{n}$-saldo środków pieniężnych na początek analizowanego roku,

$S_{n}$ - wartość przychodów ze sprzedaży w roku ubiegłym,

$K_{n}$ - wartość kosztów operacyjnych w roku ubiegłym,

$A_{n}$ - wartość kosztów amortyzacji w roku ubiegłym,

$I_{n}$ - wartość wydatków inwestycyjnych w roku ubiegłym,

$Z K F_{n+1}$ - planowana spłata krótkoterminowych zobowiązań finansowych w analizowanym roku.

\footnotetext{
${ }^{3}$ Niniejsze założenie można uznać za prawidłowe w przypadku przedsiębiorstw o ustabilizowanej pozycji rynkowej, znajdujących się w fazie dojrzałości, w których nie należy spodziewać się dużych wahań poszczególnych parametrów finansowych w kolejnych latach. Natomiast, w przypadku przedsiębiorstw znajdujących się w fazie wzrostu lub w fazie schyłkowej, dane finansowe w kolejnych latach mogą ulegać znacznym zmianom. W tej sytuacji zastosowanie prezentowanego uproszczenia może prowadzić do istotnych zniekształceń uzyskanej oceny płynności finansowej.
} 
Jak już wspomniano, dodatnia wartość planowanego salda środków pieniężnych na koniec analizowanego roku wskazuje, że przyjmując te założenia ${ }^{4}$, firma powinna utrzymać płynność finansowa. Jednak sama planowana wartość środków pieniężnych na koniec roku nie określa precyzyjnie zdolności przedsiębiorstwa do terminowego regulowania zobowiązań. Inaczej należy bowiem ocenić kondycję płynnościowa firmy, która utrzymuje saldo gotówki na poziomie 10 tys. zł, przy kosztach rocznych wynoszących 120 tys. zł oraz firmy, która również posiada 10 tys. zł, ale jej koszty roczne wynosza 120000 tys. zł. W przypadku pierwszej z firm 10 tys. zł jest kwotą wystarczająca na pokrycie średnich miesięcznych kosztów funkcjonowania. W drugiej firmie 10 tys. zł nie wystarczy nawet na spłatę średnich dziennych zobowiązań ${ }^{5}$. Ponadto, biorąc pod uwage wysoką wartość przychodów i kosztów w odniesieniu do uzyskanego planowanego salda środków pieniężnych, niewielka ich procentowa zmiana będzie w sposób bardzo istotny wpływała na wartość planowanego salda gotówki. W związku z powyższym, ze względu na stosunkowo wysokie prawdopodobieństwo wystapienia w rzeczywistości, innych niż planowano, wartości przychodów i kosztów, wysoce prawdopodobne jest, że firma realnie nie będzie dysponowała kwotą 10 tys. zł na koniec roku.

W celu wyeliminowania powyższego problemu, zaproponowano dokonywanie oceny płynności finansowej przedsiębiorstwa na podstawie wskaźnika będącego stosunkiem planowanego salda środków pieniężnych na koniec analizowanego roku do planowanej wartości średnich miesięcznych kosztów. Na potrzeby tego opracowania nazwano go zmodyfikowanym wskaźnikiem wypłacalności. Formuła jego wyliczenia przyjmuje następujący kształt:

$$
Z W W=\frac{G_{n}+S_{n}-K_{n}+A_{n}-I_{n}-Z K F_{n+1}}{\frac{1}{12} K_{n}},
$$

po przekształceniu:

$$
Z W W=\frac{12 G_{n+1}}{K_{n}},
$$

gdzie:

$Z W W$ - zmodyfikowany wskaźnik wypłacalności.

Wskaźnik ten wyraża udział planowanego salda środków pieniężnych w planowanych miesięcznych kosztach. Im jego wartość jest wyższa, tym lepiej należy ocenić zdolność firmy do terminowego regulowania zobowiązań. Zasadność stosowania zmodyfikowanego wskaźnika wypłacalności środkami pieniężnymi przedstawia poniższy przykład.

\section{Przykład 1.}

W tabeli 1. zaprezentowano historyczne (z poprzedniego roku) wartości: przychodów, kosztów operacyjnych, amortyzacji, nakładów inwestycyjnych oraz salda: zapasów, należ-

\footnotetext{
${ }^{4}$ Należy pamiętać o przyjętych uproszczeniach: przychody, koszty, nakłady inwestycyjne ukształtują się na poziomie z roku ubiegłego, nie będzie nakładów na kapitał obrotowy (nie wystąpi zmiana stanu zapasów, należności oraz zobowiązań).

${ }^{5}$ Średnie dzienne zobowiązania wynoszą około 333 tys. zł (120 000 tys. zł: 360 dni).
} 
ności, środków pieniężnych, zobowiązań krótkoterminowych handlowych oraz finansowych dla dwóch przedsiębiorstw. Na podstawie tych danych dokonano kalkulacji statycznych i dynamicznych wskaźników płynności finansowej (tabela 2.) oraz zmodyfikowanego wskaźnika wypłacalności (tabela 3.).

TABELA 1.

Dane finansowe firmy I i firmy II za ubiegły rok

\begin{tabular}{|l|r|r|}
\hline & \multicolumn{1}{|c|}{ Firma I } & \multicolumn{1}{|c|}{ Firma II } \\
\hline Przychody $\left(S_{\mathrm{n}}\right)$ & 900 & 1000 \\
Koszty operacyjne $\left(K_{\mathrm{n}}\right)$ & 800 & 820 \\
Amortyzacja $\left(A_{\mathrm{n}}\right)$ & 20 & 20 \\
Przepływ operacyjny & 120 & 200 \\
Zapasy $\left(Z_{\mathrm{n}}\right)$ & 100 & 250 \\
Należności $\left(N_{\mathrm{n}}\right)$ & 100 & 500 \\
Saldo środków pieniężnych na koniec roku $\left(G_{\mathrm{n}}\right)$ & 30 & 70 \\
Nakłady inwestycyjne $\left(I_{\mathrm{n}}\right)$ & 20 & 20 \\
Zobowiazzania krótkoterminowe, $\mathrm{z}$ wyjątkiem pożyczek & 180 & 100 \\
i kredytów $\left(Z_{\mathrm{n}}\right)$ & 100 & 300 \\
Zobowiązania krótkoterminowe finansowe $\left(Z K F_{\mathrm{n}}\right)$ & & \\
\hline
\end{tabular}

Źródło: opracowanie własne.

TABELA 2.

Statystyczne i dynamiczne wskaźniki płynności finansowej firmy I i firmy II

\begin{tabular}{|l|r|r|}
\hline & \multicolumn{1}{|c|}{ Firma I } & \multicolumn{1}{|c|}{ Firma II } \\
\hline Wskaźnik bieżącej płynności & 0,82 & 2,05 \\
Wskaźnik wysokiej płynności & 0,46 & 1,43 \\
Wskaźnik gotówkowego pokrycia zobowiązań krótko- & $11 \%$ & $18 \%$ \\
terminowych & $13 \%$ & $20 \%$ \\
Wskaźnik wydajności gotówkowej sprzedaży & $43 \%$ & $50 \%$ \\
Wskaźnik wypłacalności środkami pieniężnymi & & \\
\hline
\end{tabular}

Źródło: opracowanie własne.

W przypadku firmy I wszystkie wskaźniki płynności przyjęły wartości znacznie niższe, niż miało to miejsce w odniesieniu do firmy II. W związku z powyższym, analiza statycznych i dynamicznych wskaźników płynności finansowej pokazuje, że sytuacja płynnościowa firmy II jest znacznie lepsza niż firmy I. W celu potwierdzenia tych wyników, policzono zmodyfikowany wskaźnik wypłacalności środkami pieniężnymi. Uzyskane wyniki prezentuje tabela 3 . 
TABELA 3.

Zmodyfikowany wskaźnik wypłacalności środkami pieniężnymi dla firmy I i firmy II

\begin{tabular}{|l|r|r|}
\hline & \multicolumn{1}{|c|}{ Firma I } & \multicolumn{1}{|c|}{ Firma II } \\
\hline Planowane saldo środków pieniężnych na koniec na- & 30 & -50 \\
stępnego roku $\left(G_{\mathrm{n}+1}\right)$ & & $\mathbf{- 7 3 , 2} \%$ \\
Zmodyfikowany wskaźniki wypłacalności $(\boldsymbol{Z} \boldsymbol{W} \boldsymbol{W})$ & $\mathbf{4 5 , 0} \%$ & \\
\hline
\end{tabular}

Źródło: opracowanie własne.

Ujemna wartość planowanego salda gotówki i zmodyfikowanego wskaźnika wypłacalności środkami pieniężnymi w przypadku firmy II świadczy o tym, że jeżeli w analizowanym roku przychody, koszty oraz nakłady inwestycyjne utrzymają się na poziomie z roku ubiegłego, nie ulegnie zmniejszeniu zapotrzebowanie na kapitał obrotowy i jednocześnie planuje się spłacić wszystkie wymagalne zobowiazzania finansowe, to w firmie zabraknie pieniędzy, o ile nie zostanie ona dofinansowana ze środków obcych lub pochodzacych od właściciela. Przyjmując analogiczne założenia dotyczące zasad kalkulacji planowanej sytuacji finansowej firmy I, można zauważyć że przedsiębiorstwo utrzyma zdolność do spłaty bieżących zobowiązań. Wartość zmodyfikowanego wskaźnika wypłacalności na poziomie $45 \%$ dowodzi tego, że planowane saldo gotówki na koniec analizowanego roku będzie stanowiło $45 \%$ wartości średnich miesięcznych kosztów przedsiębiorstwa. W związku z powyższym, przeprowadzona analiza nie potwierdziła wyników uzyskanych metodą statyczną i dynamiczna, które wskazywały, że lepszą kondycją płynnościową charakteryzuje się firma II.

Biorąc pod uwagę fakty, że to przyszłe saldo gotówki określa zdolność przedsiębiorstwa do spłaty zobowiązań, zmodyfikowany wskaźnik wypłacalności środkami pieniężnymi należy uznać za lepszy miernik płynności finansowej. Informuje on w sposób bezpośredni o wysokości przybliżonego przyszłego stanu środków pieniężnych. Oczywiście, oszacowana wysokość przyszłego salda środków pieniężnych jest prawdziwa, o ile zostaną spełnione, wyżej wymienione, założenia związane z kształtowaniem się przyszłych: przychodów, kosztów, nakładów na kapitał obrotowy, nakładów inwestycyjnych i rozliczeń z tytułu finansowania działalności przedsiębiorstwa.

Podsumowując, wydaje się, że zmodyfikowany wskaźnik wypłacalności w sposób precyzyjniejszy, niż tradycyjnie stosowane wskaźniki płynności, pozwala ustalać zdolności firmy do terminowego regulowania zobowiazań. Przy założeniu, że w analizowanym roku firma osiagnie podobne wyniki finansowe do tych uzyskanych w roku ubiegłym, dodatnia wartość wskaźnika świadczy o tym, że w nadchodzącym roku firma utrzyma płynność finansowa. Ponadto, zaprezentowana formuła służy zastosowaniu jeszcze jednego, bardziej szczegółowego podejścia do szacowania wypłacalności przedsiębiorstwa. W niektórych przypadkach analityk może dysponować dodatkowymi informacjami, na podstawie których jest możliwe oszacowanie przyszłych wyników finansowych (np.: przychodów, kosztów, nakładów na kapitał obrotowy). Wykorzystując te informacje do kalkulacji przyszłego stanu gotówki oraz zmodyfikowanego wskaźnika wypłacalności, można uzyskać bardzo dokładne dane dotyczące wypłacalności przedsiębiorstwa. 
Wbrew ukazanym zaletom omawianego wskaźnika, należy podkreślić, że nie uwzględnia on wpływu sezonowości sprzedaży na ocenę płynności finansowej. Problem wypłacalności finansowej przedsiębiorstwa z uwzględnieniem sezonowości został omówiony w kolejnym podrozdziale niniejszego opracowania.

\section{Ujęcie sezonowości sprzedaży w analizie wskaźnikowej płynności finansowej}

Nierównomierne rozłożenie przychodów ze sprzedaży w poszczególnych miesiącach roku może mieć istotny wpływ na płynność finansowa przedsiębiorstwa. Wszystkie, dotąd omawiane, wskaźniki płynności nie uwzględniały powyższego problemu, tymczasem pomijanie go może doprowadzić do błędnej oceny kondycji płatniczej analizowanego podmiotu. Dotyczy to szczególnie firm, w których występuje duże zróżnicowanie w wartościach uzyskiwanych przychodów w kolejnych okresach roku obrotowego. W takich przypadkach analiza w ujęciu rocznym może wskazywać na dobrą kondycję płynnościową badanego przedsiębiorstwa, a mimo to problemy z wypłacalnościa moga pojawiać się w okresach charakteryzujących się relatywnie niskimi wpływami środków pieniężnych. Ze względu na istotę problemu, autor opracowania postanowił zaprezentować metodę kalkulacji zmodyfikowanego wskaźnika wypłacalności z uwzględnieniem sezonowości sprzedaży.

Formuła wyliczenia powyższego wskaźnika wymaga wyznaczenia planowanego salda środków pieniężnych na koniec analizowanego roku. Jeżeli chcemy badać płynność w okresach krótszych niż raz na rok, konieczne jest wyznaczenie tego salda na koniec tych okresów. Biorąc pod uwagę fakt, że większość spółek nie publikuje sprawozdań finansowych częściej niż raz na kwartał, z perspektywy analityka zewnętrznego trzeba przyjąć analizę płynności finansowej w okresach kwartalnych za optymalna, możliwą do zastosowania w praktyce. Ocena płynności finansowej z uwzględnieniem sezonowości będzie polegała zatem na wyznaczeniu zmodyfikowanego wskaźnika wypłacalności na koniec kolejnych kwartałów. W tym celu można zastosować, znaną już, formułę pozwalająca na obliczenie ZWW, jednak wykorzystując do kalkulacji dane kwartalne. Dla dowolnego kwartału formuła przyjęłaby następujący kształt:

$$
Z W W_{Q}=\frac{G_{Q}+S_{Q}-K_{Q}+A_{Q}-I_{Q}-0,25 Z K F_{n+1}}{\frac{1}{12} K_{n}},
$$

po przekształceniu:

$$
Z W W_{Q}=\frac{12 G_{Q+1}}{K_{n}},
$$

gdzie:

$G_{Q+1}$ - planowane saldo środków pieniężnych na koniec analizowanego kwartału, $G_{Q}-$ saldo środków pieniężnych na początek analizowanego kwartału, $S_{Q}$ - wartość przychodów ze sprzedaży w analizowanym kwartale, 
$K_{Q}$ - wartość kosztów operacyjnych w analizowanym kwartale, $A_{Q}$ - wartość kosztów amortyzacji w analizowanym kwartale, $I_{Q}$ - wartość wydatków inwestycyjnych w analizowanym kwartale, $Z K F_{n+1}$ - planowana spłata krótkoterminowych zobowiązań finansowych w analizowanym roku'

Jak podkreślano przy okazji prezentacji formuły pozwalającej na kalkulację salda środków pieniężnych na koniec roku, podobnie teraz należy zauważyć, że analityk dokonujący analizy może podjąć próbę zaplanowania danych finansowych lub przeprowadzić analizę na podstawie danych historycznych.

Ponadto, trzeba zwrócić uwagę na jeszcze jedną istotną kwestię. W przypadku analizy kwartalnej, przychody ze sprzedaży nie muszą równać się wpływom ze sprzedaży, a koszty operacyjne wydatkom operacyjnym ${ }^{7}$. Powyższy problem można rozwiązać, wykorzystując w tym celu znajomość wartości wskaźnika rotacji należności i zobowiązań. Informują one odpowiednio o tym, jaki okres upływa od momentu sprzedaży do momentu wpływu środków pieniężnych oraz jaki okres mija od momentu powstania zobowiązania do momentu jego spłaty. Metodyka kalkulacji wskaźników rotacji należności i zobowiązań jest prezentowana w bogatej literaturze przedmiotu [Rutkowski, 2003, s. 381-388; Pluta, 1999, s. 45; Śliwa, 1998, s. 251; Zarzadzanie finansowe..., 1998, s. 533]. Formułę, umożliwiająca kalkulację wskaźnika rotacji należności, można zapisać w następujący sposób:

$$
W R N=\frac{N}{S} x,
$$

gdzie:

WRN - wskaźnik rotacji należności,

$N$ - saldo należności na koniec okresu,

$S$ - wartość przychodów ze sprzedaży w danym okresie,

$x$ - liczba dni w okresie.

Natomiast formuła, umożliwiająca ustalenie salda zobowiązań, przyjmuje następujący kształt [Rutkowski, 2003, s. 381-388; Pluta, 1999, s. 45; Śliwa, 1998, s. 251; Zarzadzanie finansowe..., 1998, s. 586; Teoria i praktyjka..., 2002, s. 455]:

$$
W \mathrm{R} Z=\frac{Z}{K} x,
$$

gdzie:

WRZ - wskaźnik rotacji zobowiązań, $Z$ - saldo zobowiązań na koniec okresu, $K$ - wartość kosztów operacyjnych w danym okresie.

${ }^{6}$ Przyjęto założenie, że spłata krótkoterminowych zobowiązań finansowych rozłoży się równomiernie w trakcie roku, zatem na dowolny kwartał przypadnie spłata w wysokości $25 \%$ rocznej ich wartości.

${ }^{7} \mathrm{~W}$ przypadku analizy w ujęciu rocznym, zakładając, że w analizowanym roku nie będzie występowała zmiana zapotrzebowania na kapitał obrotowy, przychody ze sprzedaży będę równe wpływom ze sprzedaży, a koszty operacyjne wydatkom operacyjnym. 
W tym miejscu warto zauważyć, że w rzeczywistości, ustalony w ten sposób, wskaźnik rotacji należności (zobowiązań) nie przedstawia prawdziwych okresów rotacji charakterystycznych dla odbiorców (dostawców) przedsiębiorstwa. Uproszczenie powyższych formuł polega na założeniu, że każdego dnia wartość sprzedaży (kosztów) jest taka sama (formuła bazuje na średniej dziennej sprzedaży - w przypadku WRN oraz średnich dziennych kosztach - w przypadku WRZ). W firmach, w których przychody (koszty) nie sa rozłożone równomiernie każdego dnia w trakcie roku, zastosowanie powyższych wzorów do wyliczenia wskaźnika obrotu należnościami (zobowiązaniami) będzie prowadziło do uzyskania zniekształconych wyników [Zaawansowane techniki ..., 2010, s. 323-333]. Jednak można je urealnić, skracając okres analizy z rocznego do kwartalnego. Przykładowo, jeżeli przyjmie się założenie, że przedsiębiorstwo realizuje sprzedaż w wysokości 3600 tys. zł rocznie, a wartość należności na koniec roku wynosi 360 tys. zł, licząc wskaźnik rotacji na podstawie danych rocznych, uzyska się wartości WRN $=36$ dni $(360 / 3600 * 360)$. Jednakże, gdyby przyjąć założenie, że znaczna część przychodów, na przykład 3000 tys. zł, przypada na ostatni kwartał roku (zatem przychody nie są rozłożone równomiernie w trakcie całego roku), a jako okres kalkulacji przyjęto by kwartał, wówczas wskaźnik rotacji wyniósłby 10,8 dnia $(360 / 3000 * 90)$. Jak widać, mimo że w obydwu przypadkach roczna sprzedaż jest taka sama, to skrócenie okresu analizy powoduje zmianę uzyskanych wyników. Takie podejście umoźliwia precyzyjniejszą kalkulację wskaźnika rotacji niż miałoby to miejsce w przypadku analizy bazującej na danych rocznych. Kalkulacja przeprowadzona na podstawie danych rocznych umożliwia ustalenie średniej wartości wskaźnika rotacji dla całego roku. Jednocześnie należy podkreślić, że żadna z zaprezentowanych metod kalkulacji wskaźnika rotacji nie jest doskonała.

W celu wyznaczenia wskaźnika rotacji należności jest również możliwe zastosowanie metod: DSO, DSO $\mathrm{LIFO}_{\text {, }}$ DSOs. Jednak w tym przypadku może wystąpić problem z dostępem do danych potrzebnych do przeprowadzenia takiej analizy. Szerzej problem kalkulacji wskaźników rotacji należności został omówiony w literaturze przedmiotu [Zaawansowane techniki ..., 2010, s. 323-333; Zarzadzanie plynnościq..., 2007, s. 128-140; Kusak, 2004, s. 101-106]. Podsumowując, zadaniem analityka, dokonującego oceny płynności finansowej, jest oszacowanie w możliwie najprecyzyjniejszy sposób wskaźnika rotacji należności i zobowiązań.

Mechanizm wykorzystania znajomości wartości wskaźników rotacji do szacowania wpływów i wydatków został przedstawiony na przykładzie kalkulacji wpływów dla dowolnego kwartału. Znając średni wskaźnik rotacji należności, wiemy, ile średnio dni upływa od momentu sprzedaży do momentu wpływu środków pieniężnych. Dla celów kalkulacji wpływów w danym kwartale należy przyjąć założenie, że przychody w poszczególnych dniach danego kwartału są sobie równe, a zatem wartość dziennych przychodów w kwartale można ustalić, dzieląc przychody ze sprzedaży w danym kwartale przez 90 dni. Na podstawie informacji o średnich dziennych przychodach w poszczególnych kwartałach oraz informacji o średniej wartości wskaźnika rotacji należności można wyznaczyć wpływy ze sprzedaży w kolejnych kwartałach. Metoda kalkulacji tych wpływów będzie uzależniona od wartości wskaźnika rotacji należności. Jeżeli wskaźnik rotacji należności mieści się w przedziale: 
- $\quad$ od 0 do 90 dni - wówczas wpływy dla danego kwartału będą szacowane na podstawie przychodów z tego kwartału oraz przychodów z kwartału poprzedzająco go;

- $\quad$ od 91 do 180 dni - wówczas wpływy dla danego kwartału będą szacowane na podstawie przychodów z kwartałów, które wystapiły jeden i dwa kwartały wcześniej;

- $\quad$ od 181 do 270 dni - wówczas wpływy dla danego kwartału będą szacowane na podstawie przychodów z kwartałów, które wystapiły dwa i trzy kwartały wcześniej;

- $\quad$ od 271 do 360 dni - wówczas wpływy dla danego kwartału będą szacowane na podstawie przychodów z kwartałów, które wystapiły trzy i cztery kwartały wcześniej.

Sposób kalkulacji wpływów kwartalnych został zilustrowany przekładem.

\section{Przykład 2.}

W pewnym przedsiębiorstwie średnie dzienne przychody w I kwartale roku ubiegłego wyniosły 10 tys. zł, w II kwartale -20 tys. zł, a w III kwartale - 30 tys. zł. Wskaźnik rotacji należności wyniósł 89 dni. Przyjmuje się, że w roku następnym firma osiagnie podobne wyniki finansowe. Na podstawie zaprezentowanych danych przedstawiono sposób kalkulacji wpływów w III kwartale roku następnego. Rozważono również wariant, w którym wskaźnik rotacji należności wynosi 179 dni.

Jeżeli wskaźnik rotacji należności wynosi 89 dni, w kolejnych dniach III kwartału uzyskamy 89 razy wpływy, które będą dotyczyły przychodów zrealizowanych w kolejnych dniach II kwartału. Na przykład w 1. dniu III kwartału otrzymamy wpływy, które zostały wygenerowane przez przychody ze sprzedaży osiagnięte w 2 . dniu II kwartału. Natomiast w 2. dniu III kwartału nastąpi wpływ ze sprzedaży zrealizowanej w 3. dniu II kwartału8. Analogicznie będą kształtowały się wpływy w kolejnych dniach. Wiadomo także, że w III kwartale osiagniemy wpływ będący rezultatem sprzedaży zrealizowanej 1. dnia III kwartału. Wpływ ten nastapi dokładnie w 90. dniu III kwartału i wyniesie 30 tys. zł. Kalkulację wpływów w III kwartale można zatem zapisać w następujący sposób:

20 tys. zł (dzienny wpływ w II kw.) * 89 (dni) +30 tys. zł (dzienny wpływ w III kw.)

$$
* 1 \text { (dzień) }=1810 \text { tys. zł. }
$$

Jeśli jednak wskaźnik rotacji będzie wynosił 179 dni, wtedy wpływy w III kwartale będą w całości uzależnione od sprzedaży zrealizowanej w I i II kwartale. Uzyskamy 1 wpływ ze sprzedaży z II kwartału oraz 89 wpływów z kwartału I, w związku z tym kalkulacji wpływów można dokonać w następujący sposób:

10 tys. zł (dzienny wpływ w I kw.) * 89 (dni) +20 tys. zł (dzienny wpływ w II kw.)

$$
* 1 \text { (dzień) }=910 \text { tys. zl. }
$$

W świetle powyższych rozważań formuły, umożliwiające wyznaczenie wpływów w analizowanym kwartale, można zapisać w następujący sposób:

8 Wynika to z faktu, że na wpływy oczekujemy 89 dni od momentu dokonania sprzedaży. 
1) jeżeli wskaźnik rotacji należności mieści się w przedziale od 0 do 90 dni:

$$
W S_{Q}=\frac{S_{Q}}{90}(90-w m)+\frac{S_{Q-1}}{90} w r n,
$$

2) jeżeli wskaźnik rotacji należności mieści się w przedziale od 91 do 180 dni:

$$
W S_{Q}=\frac{S_{Q-1}}{90}(180-w r n)+\frac{S_{Q-2}}{90}(w r m-90),
$$

3) jeżeli wskaźnik rotacji należności mieści się w przedziale od 181 do 270 dni:

$$
W S_{Q}=\frac{S_{Q-2}}{90}(270-w m)+\frac{S_{Q-3}}{90}(w m-180),
$$

4) jeżeli wskaźnik rotacji należności mieści się w przedziale od 271 do 360 dni:

$$
W S_{Q}=\frac{S_{Q-3}}{90}(360-w r n)+\frac{S_{Q-4}}{90}(w r n-270),
$$

gdzie:

$W S_{Q}-$ wpływy ze sprzedaży w analizowanym kwartale;

$S_{Q}-$ wartość przychodów ze sprzedaży w analizowanym kwartale;

$S_{Q-1}$ - wartość przychodów ze sprzedaży w kwartale poprzedzającym analizowany kwartał;

$\mathrm{S}_{\mathrm{Q}-2}$ - wartość przychodów ze sprzedaży w kwartale, który wystapił dwa kwartały wcześniej niż analizowany kwartał;

$S_{Q-3}-$ wartość przychodów ze sprzedaży w kwartale, który wystąpił trzy kwartały wcześniej niż analizowany kwartał;

$S_{Q-4}$ - wartość przychodów ze sprzedaży w kwartale, który wystapił cztery kwartały wcześniej niż analizowany kwartał;

wrn - wskaźnik rotacji należności.

Zaprezentowana metodyka kalkulacji kwartalnych wpływów ze sprzedaży może zostać zastosowana do kalkulacji wydatków operacyjnych. Jednak podstawę wyliczeń w tym przypadku będą stanowiły wartości kosztów operacyjnych (zamiast przychodów) oraz wartość wskaźnika zobowiązań (zamiast wskaźnika rotacji należności). W związku z tym, formuły, umożliwiające wyznaczenie wydatków operacyjnych w analizowanym kwartale, można zapisać w następujący sposób:

1) jeżeli wskaźnik rotacji zobowiązań mieści się w przedziale od 0 do 90 dni:

$$
W O_{Q}=\frac{K_{Q}-A_{Q}}{90}(90-w r z)+\frac{K_{Q-1}-A_{Q-1}}{90} w r z,
$$

2) jeżeli wskaźnik rotacji zobowiązań mieści się w przedziale od 91 do 180 dni:

$$
W O_{Q}=\frac{K_{Q-1}-A_{Q-1}}{90}(180-\text { wrr. })+\frac{K_{Q-2}-A_{Q-2}}{90}(\text { wrz }-90),
$$

3) jeżeli wskaźnik rotacji zobowiązań mieści się w przedziale od 181 do 270 dni:

$$
W O_{Q}=\frac{K_{Q-2}-A_{Q-2}}{90}(270-w r z)+\frac{K_{Q-3}-A_{Q-3}}{90}(w r z-180) \text {, }
$$


4) jeżeli wskaźnik rotacji zobowiązań mieści się w przedziale od 271 do 360 dni:

$$
W O_{Q}=\frac{K_{Q-3}-A_{Q-3}}{90}(360-w r z)+\frac{K_{Q-4}-A_{Q-4}}{90}(w r z-270) \text {, }
$$

gdzie:

$W O_{Q}-$ wydatki operacyjne w analizowanym kwartale;

$K_{Q}$ - wartość kosztów operacyjnych w analizowanym kwartale;

$K_{Q}-1$ - wartość kosztów operacyjnych w kwartale poprzedzającym analizowany kwartał;

$K_{Q-2}$ - wartość kosztów operacyjnych w kwartale, który wystąpił dwa kwartały wcześniej niż analizowany kwartał;

$K_{Q-3}$ - wartość kosztów operacyjnych w kwartale, który wystąpił trzy kwartały wcześniej niż analizowany kwartał;

$K_{Q}-4$ - wartość kosztów operacyjnych w kwartale, który wystapił cztery kwartały wcześniej niż analizowany kwartał;

$A_{Q}$ - wartość kosztów amortyzacji w danym kwartale;

$A_{Q-1}$ - wartość kosztów amortyzacji w kwartale poprzedzającym analizowany kwartał;

$A_{Q-2}$ - wartość kosztów amortyzacji w kwartale, który wystapił dwa kwartały wcześniej niż analizowany kwartał;

$A_{Q-3}$ - wartość kosztów amortyzacji w kwartale, który wystapił trzy kwartały wcześniej niż analizowany kwartał;

$A_{Q-4}$ - wartość kosztów amortyzacji w kwartale, który wystapił cztery kwartały wcześniej niż analizowany kwartał;

wrz- -wskaźnik rotacji zobowiązań.

W kontekście powyższych rozważań ostatecznie formuła, pozwalająca na oszacowanie wartości zmodyfikowanego wskaźnika wypłacalności na koniec dowolnego kwartału, powinna przyjąć następujący kształt:

$$
Z W W_{Q}=\frac{G_{Q}+W S_{Q}-W O_{Q}-I_{Q}-0,25 \bullet Z K F_{n+1}}{\frac{1}{12} K_{n}},
$$

po przekształceniu:

$$
Z W W_{Q}=\frac{12 G_{Q+1}}{K_{n}}
$$

Zasadność stosowania zmodyfikowanego wskaźnika wypłacalności do oceny płynności finansowej w poszczególnych kwartałach zobrazowano poniższym przykładem.

\section{Przykład 3.}

W tabeli 4. zaprezentowano kwartalne wyniki finansowe dla firmy I, której plynność w ujęciu rocznym była oceniana w przykładzie 1 . Na podstawie danych kwartalnych dokonano ponownej analizy płynności finansowej. 
Dane finansowe dla firmy I

TABELA 4.

\begin{tabular}{|l|r|r|r|r|r|}
\hline & Rok n & $\begin{array}{r}\text { Rok } \\
\text { n +1 }\end{array}$ & $\begin{array}{r}\text { Rok } \\
\text { n +1 }\end{array}$ & $\begin{array}{r}\text { Rok } \\
\text { n +1 }\end{array}$ & $\begin{array}{r}\text { Rok } \\
\text { n +1 }\end{array}$ \\
\cline { 2 - 5 } & \multicolumn{1}{|c|}{ IVQ } & \multicolumn{1}{|c|}{ IQ } & IIQ & IIIQ & IVQ \\
\hline Przychody (S) & 360 & 90 & 180 & 270 & 360 \\
Koszty operacyjne (K) & 200 & 180 & 200 & 220 & 200 \\
Amortyzacja (A) & 5 & 5 & 5 & 5 & 5 \\
Należności (N) & 100 & & & & \\
Zobowiazzania krótkoterminowe, & 180 & & & & \\
z wyjątkiem pożyczek i kredytów (Z) & & 5 & 5 & 5 & 5 \\
Nakłady inwestycyjne (I) & 100 & 25 & 25 & 25 & 25 \\
Zobowiazania krótkoterminowe, & & & & & \\
z wyjątkiem pożyczek i kredytów & & & & & \\
(ZKF) & & &
\end{tabular}

Źródło: opracowanie własne.

TABELA 5.

Wpływy ze sprzedaży oraz wydatki operacyjne dla firmy I

\begin{tabular}{|l|r|r|r|r|r|}
\hline & Rok $\mathbf{n}$ & Rok $\mathbf{n}+\mathbf{1}$ & Rok n +1 & Rok n +1 & Rok n +1 \\
\cline { 2 - 6 } & \multicolumn{1}{|c|}{ IVQ } & \multicolumn{1}{c|}{ IQ } & \multicolumn{1}{c|}{ IIQ } & \multicolumn{1}{c|}{ IIIQ } & \multicolumn{1}{c|}{ IVQ } \\
\hline Wskaźnik rotacji należności & 25 & 25 & 25 & 25 & 25 \\
(wrn) & & & & & \\
Wskaźnik rotacji zobowiazzań & 81 & 81 & 81 & 81 & 81 \\
(wrz) & & 165 & 155 & 245 & 335 \\
Wpływy ze sprzedaży (WS) & & 193 & 177 & 197 & 213 \\
Wydatki operacyjne (WO) & & &
\end{tabular}

Źródło: opracowanie własne.

TABELA 6.

Wartość zmodyfikowanego wskaźnika wypłacalności dla firmy I

\begin{tabular}{|l|c|c|c|c|r|}
\hline & Rok n & $\begin{array}{c}\text { Rok } \\
\mathbf{n}+\mathbf{1}\end{array}$ & $\begin{array}{c}\text { Rok } \\
\mathbf{n}+\mathbf{1}\end{array}$ & $\begin{array}{c}\text { Rok } \\
\mathbf{n}+\mathbf{1}\end{array}$ & $\begin{array}{r}\text { Rok } \\
\mathbf{n}+\mathbf{1}\end{array}$ \\
\cline { 2 - 6 } & IVQ & IQ & \multicolumn{1}{c|}{ IIQ } & IIIQ & IVQ \\
\hline $\begin{array}{l}\text { Planowane saldo środków pienięż- } \\
\text { nych na koniec poszczególnych } \\
\text { kwartałów (G) }\end{array}$ & 30 & -28 & -80 & -62 & 30 \\
$\begin{array}{l}\text { Zmodyfikowany wskaźnik wypła- } \\
\text { calności (ZWW) }\end{array}$ & & $\mathbf{- 4 2 , 0 \%}$ & $\mathbf{- 1 2 0 , 0 \%}$ & $\mathbf{- 9 3 , 0 \%}$ & $\mathbf{4 5 , 0 \%}$ \\
\hline
\end{tabular}

Źródło: opracowanie własne. 
Analiza danych zaprezentowanych w tabeli 4 . wskazuje, że firma charakteryzuje się sezonowością sprzedaży. W związku z powyższym, powstaje pytanie, czy mimo że na koniec analizowanego roku firma utrzyma płynność finansowa (jak wynika $z$ analizy przeprowadzonej w przykładzie 1.), nie będzie miała problemów z wypłacalnością w trakcie roku obrotowego.

Znając wartość przychodów ze sprzedaży i saldo należności na koniec roku oraz wartość kosztów operacyjnych i saldo zobowiazzań krótkoterminowych (z wyłączeniem pożyczek i kredytów), wyznaczono wartość wskaźnika rotacji należności i wskaźnika rotacji zobowiązań. Następnie, stosując zaprezentowane w niniejszym opracowaniu formuły, dokonano kalkulacji wpływów ze sprzedaży i wydatków operacyjnych w poszczególnych kwartałach. Uzyskane wyniki przedstawiono w tabeli 5.

Na podstawie powyższych kalkulacji oraz założeń dotyczących wartości nakładów inwestycyjnych, a także zobowiazzań krótkoterminowych finansowych wyznaczono wartości zmodyfikowanych wskaźników wypłacalności na koniec poszczególnych kwartałów (tabela 6.).

W trzech pierwszych kwartałach otrzymano ujemną wartość planowanego salda gotówki i zmodyfikowanych wskaźników wypłacalności. Takie wyniki świadczą o tym, że jeżeli w analizowanych kwartałach przychody, koszty i nakłady inwestycyjne utrzymają się na poziomie $z$ roku ubiegłego, nie ulegnie zmniejszeniu zapotrzebowanie na kapitał obrotowy i jednocześnie planuje się spłacić wszystkie wymagalne zobowiązania finansowe, to w firmie zabraknie pieniędzy, o ile nie zostanie dofinansowana ze środków obcych lub pochodzących od właściciela. Dopiero na koniec IV kwartału osiagnięto dodatnią wartość gotówki i zmodyfikowanego wskaźnika wypłacalności. Wartości te są równe wartościom tych parametrów uzyskanych na koniec roku w przykładzie 1., w którym oceniano płynność tej samej firmy, ale w ujęciu rocznym. Taki wynik nie jest zaskoczeniem. Zarówno w przykładzie 1., jak i 3. oceniono płynność finansową tej samej firmy. Analiza płynności dokonana na koniec roku, przeprowadzona w przykładzie 1., jest tożsama z analizą na koniec IV kwartału, która została zaprezentowana w przykładzie 3. Zbieżność otrzymanych wyników świadczy o spójności przedstawionych modeli oceny płynności finansowej w układzie rocznym i kwartalnym.

Jednocześnie należy podkreślić, że ten przykład ukazuje potrzebę prowadzenia analiz płynności finansowej w krótszych okresach niż jeden rok, szczególnie w firmach charakteryzujących się sezonowością sprzedaży. Analiza płynności w ujęciu rocznym nie wskazywała na ryzyko wystapienia problemów z utrzymaniem płynności finansowej w firmie I, tymczasem badanie w okresach kwartalnych pokazuje, że w trakcie roku może mieć duże trudności z terminowym regulowaniem bieżących zobowiązań.

\section{Podsumowanie}

Powszechnie stosowane w ocenie płynności finansowej statyczne oraz dynamiczne wskaźniki nie pozwalają na dokonanie precyzyjnej analizy wypłacalności przedsiębiorstwa.

\footnotetext{
${ }^{9}$ Wartość wskaźnika rotacji należności wyznaczono stosując w tym celu, prezentowaną w opracowaniu, formułę: WRN=N/S*x $(100 / 360 * 90=25)$. Natomiast wartość wskaźnika rotacji zobowiązań wyznaczono stosując w tym celu, prezentowaną w opracowaniu, formulę: WRZ=Z/K*dni $(180 / 200 * 90=81)$.
} 
Zarówno statyczna, jak i dynamiczna analiza wskaźnikowa może prowadzić do błędnych wniosków dotyczących oceny płynności finansowej przedsiębiorstwa. Z tego względu, w niniejszym opracowaniu przedstawiono koncepcję zmodyfikowanego wskaźnika wypłacalności, umożliwiająca przeprowadzenie oceny płynności finansowej przedsiębiorstwa w sposób dokładniejszy, niż jest to możliwe, wykorzystując tradycyjnie stosowane wskaźniki płynności finansowej. Główna zaleta tego podejścia polega na tym, że uwzględnia ono łącznie wszystkie podstawowe determinanty płynności finansowej przedsiębiorstwa, tzn.: stan początkowy środków pieniężnych i planowane przyszłe całkowite przepływy pieniężne (przepływy operacyjne, inwestycyjne oraz finansowe). Ponadto, w artykule zwrócono również uwagę na istotę analizy płynności finansowej w okresach krótszych niż rok obrotowy, a także zaproponowano model jej pomiaru.

Jednocześnie należy podkreślić, że ukazane w opracowaniu rozwiązania nie są pozbawione wad. Wśród nich należy przede wszystkim wymienić:

- $\quad$ kalkulację pomiaru płynności finansowej w roku analizowanym na podstawie danych finansowych, pochodzących z roku poprzedniego lub konieczność przeprowadzenia czasochłonnych prognoz danych finansowych;

- złożoność prezentowanej metody kalkulacji;

- wyższą czasochłonność i pracochłonność przedstawionej metody w porównaniu z metodami stosowanymi tradycyjnie.

Niemniej, jak pokazują przeprowadzone analizy, w większości przypadków zmodyfikowany wskaźnik wypłacalności umożliwia precyzyjniejszy pomiar płynności finansowej niż tradycyjnie stosowane statyczne i dynamiczne wskaźniki płynności finansowej. Z tej racji warto rozważyć jego wykorzystanie w procesie oceny płynności finansowej przedsiębiorstwa.

\section{Literatura}

Bednarski L. 2001 Analiza finansowa w przedsiebiorstwie, PWE, Warszawa.

Bednarski L., Borowiecki R., Duraj J., Kurtys E., Waśniewski T., Wersty B. 2001 Analiza ekonomiczna przedsiebiorstwa, Wydawnictwo Akademii Ekonomicznej im. Oskara Langego we Wrocławiu, Wrocław.

Bernstein L. 1993 Analysis of Financial Statement, Irwin, Homewood.

Brealey R.A., Myers S.C., Allen F. 2011 Principle of Corporate Finance, The McGraw-Hill, New York.

Carslaw C.A., Mills J.R. 1991 Developing Ratios For Effective Cash Flow Statement Analysis, „Journal of Accountancy”, 172 (5).

Gajdka J., Walińska E. 1998 Zarzqdzanie finansowe. Teoria i praktyka. Tom 2, Fundacja Rozwoju Rachunkowości w Polsce, Warszawa.

Gąsiorkiewicz L. 1999 Ekonomika przedsiębiorstwa. Analiza ekonomiczna przedsiebiorstwa, Oficyna Wydawnicza Politechniki Warszawskiej, Warszawa.

Giacomino D.E., Mielke E. D. 1993 Cash flow: Another Approach to Ratio Analysis, ,Journal of Accounting", 175 (3).

Gotlieb M., Lewczyński W. 1993 Cash flow, sprawozdanie z.przeptywón gotónki, Instytut Przedsiębiorczości, Sopot. 
Horrigan J. O. 1965 Some Empirical Bases of Financial Ratio Analysis, „The Accounting Review", 40 (3).

Kacprzyk M., Wolski R., Bolek M. 2012 Analiza wplywu wskaźnikón plynności oraz rentowności na ksztattowanie sie ekonomicrnej wartości dodanej na pryyktadrie spótek. notowanych na GPW w Warszanie, [w:] Zarzadzanie finansami firm - teoria i praktyka, A. Kopiński, T. Słoński, B. Ryszawska (red.), Prace Naukowe Uniwersytetu Ekonomicznego we Wrocławiu nr 271, Wydawnictwo Uniwersytetu Ekonomicznego we Wrocławiu, Wrocław.

Kirkham R. 2012 Liquidity Analysis Using Cash Flow Ratios and Traditional Ratios: The Telecommunications Sector in Australia, „Journal of New Business Ideas \& Trends”, 10(1).

Kusak A. 2004 Plynnosí finansowa. Analiza i sterowanie, Wydawnictwo Naukowe Wydziału Zarządzania Uniwersytetu Warszawskiego, Warszawa.

Emery G., Cogger K. 1982 The measurement of Liquidity, „Journal of Accounting Research", 20(2).

Figlewicz R.E., Zeller T.L. 1991 An Analysis of Performance, Liquidity, Coverage and Capital Ratios from Statement of Cash Flow, Akron Business and Economic Review, 22(1).

Levy H., Alderson M. J. 1998 Principle of Corporate Finance, South-Western Collage Publishing, Ohio.

Nowak M. 1998 Praktycżna ocena kondycji finansowej przedsiebiorstwa. Metody i ograniczenia, Fundacja Rozwoju Rachunkowości w Polsce, Warszawa.

Ostaszewski J. 1991 Ocena efektywności przedsiebiorstwa wedtug standardów EWG, CIM, Warszawa.

Parkinson K., Kallberg J. 1993 Corporate Liquidity. A Guide to Managing Working Capital, Irwin, Homewood.

Pluta W. 1999 Planowanie finansowe w przedsiebiorstwie, PWE, Warszawa.

Richards V. D., Laughlin E. J. 1980 A cash conversion cycle approach to liquidity analysis, Financial Management, 9(1).

Rutkowski A. 2003 Zarzadzanie finansami, PWE, Warszawa.

Sierpińska M., Jachna T. 1994 Ocena pręedsiebiorstwa wedlug standardów swiatonych, Wydawnictwo Naukowe PWN, Warszawa.

Sierpińska M., Wędzki D. 2007 Zarz̨adzanie plynnościa finansowa w przedsiębiorstwie, Wydawnictwo Naukowe PWN, Warszawa.

Szczepaniak J. 1992 Ocena pržedsiebiorstwa na podstawie sprawozdań finansonych, Ekorno, Lódź.

Śliwa J. 1998 Zarzqdzanie finansami pržedsiebiorstwa, Fundacja Rozwoju Rachunkowości w Polsce, Warszawa.

Walter J. 1975 Determination of Technical Solvency, ,Journal of Business”, 30 (1).

Wędzki D. 2009 Analiza wskaźnikowa sprawozdania finansowego. Tom 2. W skaźniki finansowe, Wolters Kluwer Polska, Kraków.

Wiśniewski T., Skoczylas W. 2002 Teoria i praktyka analisy finansowej w przedsiębiorstwie, Fundacja Rozwoju Rachunkowości w Polsce, Warszawa.

Wnuczak P., Cegłowski B. 2010 Zaawansowane techniki planowania należności i zobowiazań bandlowych, [w:] Cras na pieniad₹. Zarzadzanie finansami. Analiza finansowa $i$ zarzadzanie rysykiem, D. Zarzecki (red.), Zeszyty Naukowe nr 587, Uniwersytet Szczeciński, Szczecin. 